\title{
ROLE OF HERBAL ANTIFUNGAL AGENTS FOR THE MANAGEMENT OF FUNGAL DISEASES: A SYSTEMATIC REVIEW
}

\author{
KUSUM KAUSHIK*, SHWETA AGARWAL
}

Department of Pharmaceutics, LR Institute of Pharmacy, Solan, Himachal Pradesh, India. Email: kaushikkusum081994@gmail.com

Received: 29 April 2019, Revised and Accepted: 28 May 2019

\section{ABSTRACT}

Nowadays, fungal infection of skin is one of the most common dermatological problems worldwide. It has been investigated that 40 million people suffer from fungal infections. Superficial and subcutaneous fungal infections affect the skin, keratinous tissues, and mucous membranes. The dermatophytic infections, superficial candidiasis of the mouth, skin, or genital tract and infections due to Malassezia, such as pityriasis versicolor and Malassezia folliculitis are the main afflicting conditions. Systemic fungal infections may be caused by either an opportunistic organism that infects an at-risk host or may be associated with a more invasive organism or may be endemic to a specific geographical area. The most frequently encountered pathogens are Candida albicans and Aspergillus spp. but other fungi such as non-albicans Candida spp. are increasingly important in causing systemic fungal infections. There are numerous antifungal agents used clinically to treat fungal infections, i.e., azoles, allylamines, echinocandins, griseofulvin, and flucytosine. The course to modern treatment has not been without its problems and complications, particularly the drug resistances. Phytochemistry of various plant species has indicated that the phytochemicals could be a better source of medicine as compared to synthetically produced drugs. Natural medicines from a plant origin are still used as therapeutic agents, especially for treating bacterial, fungal, viral, protozoal, helminthic infections, etc. This review focuses on the use of plant constituents to prevent fungal infections caused by various pathogens. Hence, it will be proved beneficial for the drug industries.

Keywords: Fungal infection, Dermatophyte, Pityriasis versicolor, Pathogens, Endemic, Natural medicines.

(C) 2019 The Authors. Published by Innovare Academic Sciences Pvt Ltd. This is an open access article under the CC BY license (http://creativecommons. org/licenses/by/4. 0/) DOI: http://dx.doi.org/10.22159/ajpcr.2019.v12i7.33831

\section{INTRODUCTION}

The humans live in peaceful coexistence with the surrounding microorganisms but an infection may emerge from the surrounding microorganisms when the defense system is damaged or the concentration of pathogens reach an exceptionally high density whereas infectious disease is a condition in which the infecting agents do elicit a response of the body, which leads to clinically manifest signs and symptoms. Bacteria, viruses, parasites, fungi, prions, worms, and helminths have all been involved in causing infectious diseases. A few decades ago, an infection caused by bacteria was the most feared and as the strategies to control bacterial infections in patients improved, but nowadays, fungi are the most hazardous pathogens [1]

Fungi exist in two basic forms: Yeasts and molds. Yeasts are typically single, small, and oval cells, whereas mold colonies consist of filamentous strands called hyphae. Some fungi are dimorphic, exists either as yeasts or molds depending on the external environment such as temperature [2,3]. Fungi are ubiquitous within the environment; however, only a few species are routinely found associated with humans who are capable of causing disease. A handful of fungi that is responsible for causing disease in healthy individuals are considered as true pathogens, (Histoplasma and Paracoccidioides), while the majority of fungi causing disease primarily in immuno-suppressed individuals are often classified as opportunistic pathogens (Candida and Cryptococcus) [4]. However, it is obvious that some opportunistic fungal pathogens also cause disease in otherwise healthy individuals (Candida vaginitis or Cryptococcus gattii outbreaks) [5,6]. Invasive fungal infections are characterized by high morbidity and mortality, although these infections are now more frequent they are still difficult to diagnose, prevent, and treat. [7]

For a systemic effect, the intravenous or oral route is mainly used to treat topical fungal infection. However, it causes many side effects, including gastric irritation, diarrhea, nausea, vomiting and stomach pain, headache, fever, renal impairment, and anemia. Hence, the topical drug delivery is the most suitable routes for the administration of drugs that undergo first-pass metabolism. It is generally effective against fungal infections [8]. By spreading and rubbing ointments, creams, and gels applied directly to an external body surface for topical administration of drugs to the skin. For the therapeutic effect, the drug must permeate and diffuse across the skin $[9,10]$. The rate and extent of transport depend on the drug molecular properties and the characteristic of the biologic tissue. Advantages of the topical treatment of fungal infections include targeting the site of infection; increase the efficacy of treatment, reduction in the risk of systemic side effects, and to increase the patient compliance [11].

There are numerous antifungal agents used clinically to treat fungal infections and can be broadly classified into five major classes, i.e., azoles, allylamines, echinocandins, griseofulvin, and flucytosine [12]. Although the course to modern treatment has not been without its problems and complications, particularly the drug resistances which have not had a major impact on the currently used antifungals with the exception of superficial Candidiasis infections; however, azole resistance is well recognized. The rise of Candida auris as a pathogen, which is resistant to multidrug is a further worry although it has not had a major impact on skin infection, superficial carriage is well documented [13-16].

Therefore, the discovery of novel antifungals is severely needed. Phytochemistry of various plant species has indicated that the phytochemicals could be a better source of medicine as compared to synthetically produced drugs. The use of plants as medicine goes back to early man. These traditional medicines based on medicinal plants have been used for centuries. Therefore, one approach that has been used for the discovery of antimicrobial agents is the evaluation of plant extracts [17].

\section{TYPES OF FUNGAL INFECTIONS}

Topical/superficial disease caused by fungal pathogens Superficial fungal infections occur in the outermost layers of the skin, nails, hair, and mucous membranes [18]. 


\section{Dermatophytosis}

Dermatophyte fungi are organisms that digest keratin [19]. Dermatophytes infect the stratum corneum of the epidermis and keratinized tissues derived from it, such as hair or nail. Trichophyton spp., Microsporum spp., and Epidermophyton spp. are responsible for most of the superficial fungal infections, although the causative agents can be some yeast and some non dermatophyte molds [20].

Tinea pedis

Tinea pedis is a dermatophyte infection of the foot, affecting particularly the toes and sole caused mainly by Trichophyton rubrum, Trichophyton mentagrophytes, and Epidermophyton floccosum pathogens. This infection affects $15-30 \%$ of the population [21] and is the most common dermatophyte fungal disease that occurs in man [22]. Individuals with tinea pedis may be susceptible to secondary bacterial infection with, for example, Group A streptococcus [23].

Tinea corporis

Two major causative organisms causing tinea corporis are T. rubrum, T. mentagrophytes affecting neck, trunk, and the extremities. The classic tinea corporis lesion is a sharply defined circular lesion with erythema, scaling, and small blisters or pustules at the border. The lesion is usually $<5 \mathrm{~cm}$ in diameter. The fungus is often transmitted from domestic animals, such as cats, dogs, hamsters, and guinea pigs to humans [21].

\section{Tinea capitis}

The predominant causative agent of this infection is Trichophyton tonsurans and mainly causes disease in childhood, presenting with alopecia and scaling on the scalp $[24,25]$

Tinea unguium or onychomycosis (nails)

T. rubrum and T. mentagrophytes dermatophytes are the principal causes of onychomycosis, accounting approximately for $90 \%$ of toenail infections and $50 \%$ of fingernail infections [26-28].

\section{Superficial candidiasis}

Superficial candidiasis infections are usually caused by Candida albicans, and this organism is a common commensal in the mouth, vagina, and gastrointestinal tract in healthy individuals. The prevalence of carriage is greater in hospitalized patients and those who are immuno-compromised.

Oropharyngeal candidiasis (oral thrush)

It has typical symptoms and signs of soreness and white patches on an erythematous background (plaque type). An erythematous variety exists; this does not have plaques, but sore areas of erythema are typical. Acute or chronic infection can occur in immuno-compromised individuals. Other predisposing factors include antibiotic therapy and dentures.

Vaginal candidiasis (vaginal thrush)

Vaginal candidiasis is a common infection, with clinical appearances similar to those of oropharyngeal disease, plus vaginal discharge. Pruritus can also occur, and recurrent episodes are common. Women with vaginal thrush seldom have underlying predisposing factors.

Candidiasis of the skin

Candidiasis of the skin is often confined to body folds, including the inter-digital spaces of the hands or feet. Typically, small satellite pustules lie distal to the periphery of the rim of the rash. Chronic paronychia (nail fold infections) can be caused by Candida.

\section{Malassezia infection}

Malassezia spp. are common surface commensals of greasy skin includes scalp, chest, and they are associated with pityriasis versicolor, seborrheic dermatitis, and folliculitis [29].

\section{Pityriasis versicolor}

Pityriasis versicolor is a scaly, hypo- or hyper-pigmented rash on the trunk which is found common in tropical regions and the patches can resemble vitiligo, but the presence of scaling is typical.

\section{Seborrheic dermatitis}

Seborrheic dermatitis is a common scaly condition affecting the face, the front of the chest, and the scalp. Severe seborrheic dermatitis is particularly common in patients with AIDS or chronic neurological Parkinson's disease.

\section{Malassezia folliculitis}

Malassezia folliculitis is an itchy, follicular rash on the upper back and shoulders that can resemble acne [30].

\section{Subcutaneous infection}

Although subcutaneous mycoses can disseminate, they are usually limited to the dermis and subcutaneous tissues.

\section{Sporotrichosis}

Sporotrichosis is caused by the dimorphic fungus Sporothrix schenckii and is the most prevalent subcutaneous infection [31]. The fungus is found in soil, vegetation and usually causes disease in farmers or gardeners, especially those who tend roses. It is a localized cutaneous or subcutaneous lesion, which may spread via the lymphatic system and form further lesions. Lymphocutaneous sporotrichosis is a nonlife-threatening disease [32].

\section{Chromoblastomycosis}

Chromoblastomycosis is a chronic cutaneous or subcutaneous fungal infection caused by members of the Dematiaceae family including Fonsecaea pedrosoi, Cladosporium carrionii, Fonsecaea compacta, Phialophora verrucosa, and Rhinocladiella aquaspersa and found in wood, vegetable debris, and soil [33]. Symptoms are raised, crusted lesions of the skin.

\section{Chronic mucocutaneous candidiasis}

Chronic mucocutaneous candidiasis is a rare syndrome consisting of chronic infection of mucous membranes usually by $C$. albicans, which may extend to the skin and nails. The condition is associated with impaired cell-mediated responses to Candida, although the underlying defect remains poorly understood [34,35]. Various manifestations including white fissured lesions; hyperkeratotic, granulomatous and vegetating lesions, autosomal recessive trait associated with endocrine disorders, for example, hypoparathyroidism.

\section{Systemic fungal infections}

Systemic fungal infections can be divided into two distinct groups: The endemic or dimorphic mycoses. These infections are caused by true pathogenic fungi as compared with the opportunistic mold and yeast infections that are saprophytes, which only will invade an immunocompromised host [36,37]. Such infections are life-threatening and are associated with high rates of death. Solid organ transplant recipients who take immunosuppressive medications to limit the risk of rejection also have an increased susceptibility to systemic fungal infections $[2,3]$.

\section{Opportunistic pathogens}

Invasive candidiasis

At present, Candida spp. rank as the fourth most frequent cause of nosocomial bloodstream infections [38,39]. Nosocomial candidiasis may be either endogenous which is acquired through previous colonization of the mouth, gastrointestinal tract, vagina or skin or by exogenous which is acquired by cross-infection from another patient or healthcare worker [40]. C. albicans is the most frequently isolated species, causing $48-60 \%$ of bloodstream fungal infections $[38,41,42]$. However, a change in the pattern of Candida-related disease has been resulting in the emergence of a number of important non-albicans Candida spp., such as Candida krusei, Candida parapsilosis, Candida tropicalis, and Candida glabrata $[38,41,43]$. This epidemiological change has major clinical implications by some non-albicans Candida spp. and has higher complication and death rates than $C$. albicans infections, and some species are resistant to antifungal agents [44,45]. 
Table 1: Classification of medicinal plants according to the bioactive compounds present in the plant for antifungal activity

\begin{tabular}{|c|c|c|c|}
\hline S. No. & $\begin{array}{l}\text { Bioactive } \\
\text { compounds }\end{array}$ & Plant & The chemical constituent for antifungal activity \\
\hline 1 & Polyphenols & & \\
\hline 1.1 & & $\begin{array}{l}\text { Baseonema } \\
\text { acuminatum }\end{array}$ & $\begin{array}{l}\text { Three phenolic compounds, 1-galloyl- } \beta \text {-D-glucopyranosyl-(1->4)- } \beta \text {-D galactopyranoside, } \\
\text { 2-methoxy-5-(1',2',3'-trihydroxypropyl) phenyl-1-O-(6"-galloyl)- } \beta \text {-D-glucopyranoside and } \\
\text { 2-methoxy-5-hydroxymethyl-phenyl-1- } O \text { - }\left(6^{\prime \prime} \text {-galloyl }\right)-\beta \text {-D-glucopyranoside together were } \\
\text { reported for antifungal activity against Candida albicans [82] }\end{array}$ \\
\hline 1.2 & & Cuban propolis & $\begin{array}{l}\text { A novel polyisoprenylated benzophenone showed significant antimicrobial and antifungal } \\
\text { activities against a variety of bacteria and yeasts [83] }\end{array}$ \\
\hline 1.3 & & $\begin{array}{l}\text { Garcinia } \\
\text { mangostana }\end{array}$ & $\begin{array}{l}\text { Geranylated biphenyl derivative 3-hydroxy-4-geranyl-5 methoxybiphenyl has strong antifungal } \\
\text { and a number of other biological activities [84] }\end{array}$ \\
\hline 1.4 & & $\begin{array}{l}\text { Isolona cauliflora } \\
\text { and Monodora } \\
\text { angolensis }\end{array}$ & Some of the prenylindoles had antifungal and antimalarial activities [85] \\
\hline 1.5 & & Lycium chinense & $\begin{array}{l}\text { Dihydro- } N \text {-caffeoyltyramine, trans- } N \text { feruloyloctopamine, trans- } N \text { caffeoyltyramine, and } \\
\text { cis- } N \text {-caffeoyltyramine reported to have anti-fungal activity [86] }\end{array}$ \\
\hline 1.6 & & Toronia toru & $\begin{array}{l}\text { 4-Hydroxyphenyl-6-0-[(3R)-3,4- dihydroxy-2-methylenebutanoyl]-D-glucopyranoside has the } \\
\text { main antimicrobial component of the crude extract [87] }\end{array}$ \\
\hline 2. & Flavonoids & & \\
\hline 2.1 & & Artemisia giraldii & $\begin{array}{l}\text { The flavones hispidulin and belamcanidin were shown to inhibit the growth of the broad range of } \\
\text { human pathogenic fungi [88] }\end{array}$ \\
\hline 2.2 & & Aquilegia vulgaris & $\begin{array}{l}\text { 4-methoxy-5,7-dihydroxyflavone 6-Cglucoside (isocytisoside) showed activity against the mold } \\
\text { Aspergillus niger [89] }\end{array}$ \\
\hline 2.3 & & Adina cordifolia & $\begin{array}{l}\text { A flavon 3,4,5,7-tetraacetyl quercetin exihibited moderate antifungal activity against Aspergillus } \\
\text { fumigatus and Cryptococcus neoformans [90] }\end{array}$ \\
\hline 2.4 & & $\begin{array}{l}\text { Hildegardia } \\
\text { barteri }\end{array}$ & An isoflavone, 2-hydroxy maackiain was observed to have antifungal activity [91] \\
\hline 2.5 & & Malus sylvestris & Flavonoid derivative phloretin has antifungal properties [92] \\
\hline 2.6 & & Piper solmsianum & $\begin{array}{l}\text { The four compounds eupomatenoid-3, eupomatenoid-5, conocarpan, and orientin exhibited } \\
\text { antifungal action against all the dermatophytes tested [93] }\end{array}$ \\
\hline 2.7 & & $\begin{array}{l}\text { Selaginella } \\
\text { tamariscina }\end{array}$ & Amentoflavone exhibited potent antifungal activity [94] \\
\hline 3 & Coumarins & & \\
\hline 3.1 & & $\begin{array}{l}\text { Clausena } \\
\text { excavate }\end{array}$ & $\begin{array}{l}\text { Clausenidin, dentatin, nor-dentatin, and carbazole derivatives, and clauszoline J showed } \\
\text { antimycotic activity [95] }\end{array}$ \\
\hline 3.2 & & Melia azedarach & Hydroxycoumarin scopoleti reported to be antifungal against Fusarium verticillioides [96] \\
\hline 3.3 & & Senecio poepigii & $\begin{array}{l}\text { A bioactive eremophilanolide, 1-tigloyloxy-8bH,10bH-eremophil- } 7 \text { (11)-en-8a, 12-olide showed } \\
\text { antifungal properties [97] }\end{array}$ \\
\hline 3.4 & & $\begin{array}{l}\text { Tordylium } \\
\text { apulum }\end{array}$ & $\begin{array}{l}\text { An antifungal dihydrofuranocoumarin, } \\
20(\mathrm{~S}), 30(\mathrm{R})-20 \text {-acetoxyisopropyl- 30-acetoxy-20,30-dihydroangelicin, were reported [98] }\end{array}$ \\
\hline 4 & Quinones & & \\
\hline 4.1 & & $\begin{array}{l}\text { Annona } \\
\text { squamosa }\end{array}$ & A compound, 11-hydroxy-16-hentriacontanone was reported for its antifungal potential [99] \\
\hline 4.2 & & Kigelia pinnata & $\begin{array}{l}\text { The naphthoquinones kigelinone, isopinnatal, dihydro-a-lapachone were reported for antifungal } \\
\text { activity [100] }\end{array}$ \\
\hline 4.3 & & $\begin{array}{l}\text { Rubia tinctorum } \\
\text { and Rhamnus } \\
\text { frangula }\end{array}$ & Alizarin and emodin are the major anthraquinone aglycones for antifungal activity [101] \\
\hline 5 & Saponoins & & \\
\hline 5.1 & & $\begin{array}{l}\text { Phytolacca } \\
\text { tetramera }\end{array}$ & $\begin{array}{l}\text { Phytolaccosides B and showed antifungal activities against a panel of human pathogenic } \\
\text { opportunistic fungi [102] }\end{array}$ \\
\hline 5.2 & & $\begin{array}{l}\text { Sansevieria } \\
\text { ehrenbergii }\end{array}$ & $\begin{array}{l}\text { Three spirostanol saponins designated sansevierin A, sansevistatin 1, and sansevistatin } 2 \text { and } \\
\text { three steroidal exhibited antimicrobial activities, particularly against the pathogenic fungi Candida } \\
\text { albicans and Candida neoformans [103] }\end{array}$ \\
\hline 5.3 & & Smilax medica & $\begin{array}{l}\text { Spirostanol steroidal saponins together with the smilagenin 3-0-b-Dglucopyranoside and } \\
\text { disporoside A exhibited antifungal activity against the human pathogenic yeasts Candida albicans, } \\
\text { Candida glabrata, and Candida tropicalis [104] }\end{array}$ \\
\hline 5.4 & & $\begin{array}{l}\text { Ypsilandra } \\
\text { thebetica }\end{array}$ & $\begin{array}{l}\text { Recently, steroidal saponins ypsilandroside B, ypsilandroside A, isoypsilandroside A, } \\
\text { isoypsilandroside B, and isoypsilandrogaine were reported for antimicrobial activities [105] }\end{array}$ \\
\hline 6 & Xanthones & & \\
\hline 6.1 & & $\begin{array}{l}\text { Calophyllum } \\
\text { caledonicum }\end{array}$ & Caledonixanthone E was reported for strong antifungal activity [106] \\
\hline 6.2 & & $\begin{array}{l}\text { Cudrania } \\
\text { fruticosa }\end{array}$ & $\begin{array}{l}\text { Isoprenylated xanthone, cudrafrutixanthone which showed antifungal activity against Candida } \\
\text { albicans [107] }\end{array}$ \\
\hline 6.3 & & $\begin{array}{l}\text { Monnina } \\
\text { obtusifolia }\end{array}$ & 1,3,6- Trihydroxy-2,5 dimethoxyxanthone was reported to have the antifungal potential [108] \\
\hline 6.4 & & $\begin{array}{l}\text { Securidaca } \\
\text { longepedunculata }\end{array}$ & $\begin{array}{l}\text { The dichloromethane yielded 1,7-dihydroxy- 4-methoxyxanthone, which exhibited antibacterial } \\
\text { activity against Staphylococcus aureus and antifungal activity against Aspergillus niger, Aspergillus } \\
\text { fumigatus, and a Penicillium species [109] }\end{array}$ \\
\hline
\end{tabular}


Table 1: (Continued)

\begin{tabular}{|c|c|c|c|}
\hline S. No. & $\begin{array}{l}\text { Bioactive } \\
\text { compounds }\end{array}$ & Plant & The chemical constituent for antifungal activity \\
\hline 7 & Alkaloids & & \\
\hline 7.1 & & Aniba panurensis & $\begin{array}{l}\text { 6,8-didec-(1Z)-enyl-5,7-dimethyl-2,3-dihydro-1H-indolizinium from Aniba panurensis } \\
\text { demonstrated the activity against drug-resistant strains of Candida albicans [110] }\end{array}$ \\
\hline \multirow[t]{2}{*}{7.2} & & Corydalis & The alkaloids N-methylhydrasteine hydroxylactam and 1-methoxyberberine chloride from \\
\hline & & longipes & Corydalis longipes showed high efficacy individually [111] \\
\hline 7.3 & & Datura metel & $\begin{array}{l}\text { Recently, an alkaloid, 2-(3,4-dimethyl-2,5-dihydro-1H-pyrrol-2-yl)-1-methylethyl pentanoate, has } \\
\text { been isolated from the plant Datura metel and showed in vitro as well as in vivo activities against } \\
\text { Aspergillus and Candida species [112] }\end{array}$ \\
\hline 7.4 & & $\begin{array}{l}\text { Epinetrum } \\
\text { villosum }\end{array}$ & $\begin{array}{l}\text { Cocsoline, a bisbenzylisoquinoline alkaloid from the Epinetrum villosum displayed antifungal } \\
\text { activities [113] }\end{array}$ \\
\hline 7.5 & & Melochia odorata & $\begin{array}{l}\text { Frangulanine, a cyclic peptide alkaloid, and waltherione A, a quinolinone alkaloid from leaves } \\
\text { of Melochia odorata, were reported to exhibit antifungal activities against a broad spectrum of } \\
\text { pathogenic fungi [114] }\end{array}$ \\
\hline 7.6 & & $\begin{array}{l}\text { Zanthoxylum } \\
\text { chiloperone var. } \\
\text { angustifolium }\end{array}$ & $\begin{array}{l}\text { Canthin-6-one and 5-methoxy-canthin-6-one of Zanthoxylum chiloperone var. angustifolium } \\
\text { exhibited antifungal activity against Candida albicans, Aspergillus fumigatus and Trichophyton } \\
\text { mentagrophytes [115] }\end{array}$ \\
\hline 8 & $\begin{array}{l}\text { Terpenoids } \\
\text { and essential } \\
\text { oil }\end{array}$ & & \\
\hline 8.1 & & $\begin{array}{l}\text { Delphinium } \\
\text { denudatum }\end{array}$ & $\begin{array}{l}\text { The roots of yield 8-acetylheterophyllisine, panicutine, and 3-hydroxy-2-methyl-4H-pyran-4-one } \\
\text { which have shown antifungal activity against a number of human pathogenic fungi [116] }\end{array}$ \\
\hline 8.2 & & Litsea cubeba & $\begin{array}{l}\text { The essential oil from the leaves of have } \alpha \text {-cis-ocimene, 3,7-dimethyl-1,6-octadien-3-ol and } \\
\text { ntransnerolidol had manifest antifungal activities with minimal inhibitory concentration between } \\
0.03 \text { and } 0.4 \mu \mathrm{L} / \mathrm{mL} \text { for utilized pathogenic fungi and } 1.0-2.0 \mu \mathrm{L} / \mathrm{mL} \text { for molds [117] }\end{array}$ \\
\hline \multirow[t]{2}{*}{8.3} & & Polyalthia & The diterpenoids 16ahydroxy-cleroda-3,13 (14)-Z-diene-15,16-olide and \\
\hline & & longifolia & $\begin{array}{l}\text { 16-oxo-cleroda-3,13 (14)-Ediene-15-oic acid isolated from the hexane extract of the seeds } \\
\text { demonstrated significant antifungal activity [118] }\end{array}$ \\
\hline 8.4 & & $\begin{array}{l}\text { Vernonanthura } \\
\text { tweedieana }\end{array}$ & $\begin{array}{l}\text { The afforded one antifungal active sesquiterpene, } \\
\text { 6-cinnamoyloxy-1-hydroxyeudesm-4-en-3- one [119] }\end{array}$ \\
\hline 9 & Polypeptides & & \\
\hline 9.1 & & Cicer arietinum & A peptide designated cicerarin showed antifungal activity [120] \\
\hline 9.2 & & Black pumpkin & A novel antifungal peptide, cucurmoschin, inhibited mycelial growth in the fungi [121] \\
\hline
\end{tabular}

Invasive aspergillosis

Aspergillus spp. is ubiquitous, occurring most frequently in soil, water, and decaying vegetation. Most Aspergillus infections are acquired through the respiratory tract inhalation and are associated with hospital construction work or contaminated ventilation systems. Infections may also be acquired from plants or certain foods such as pepper. Sign and symptoms include: Unremitting fever and pulmonary infiltrates during antibiotic therapy, chest pain, pleural rub, pleural effusion, and hemoptysis. Computed tomography scan shows characteristic halo and air crescent signs while radiography reveals single or multifocal lesions [46].

\section{Cryptococcus}

Cryptococcal infection usually results from the inhalation of Cryptococcus neoformans, which is found primarily in soil contaminated by pigeon or chicken excreta. Cryptococcus has a particular affinity for the central nervous system, resulting in Cryptococcal meningitis, and is one of the most significant life-threatening fungal infections associated with HIV [47]. Cryptococcal infection may also be seen in non-immunocompromised individuals [48] and patients with impaired cell-mediated immunity, for example, that undergoing solid organ transplantation [49].

\section{Zygomycosis}

Fungal infections from the class Mucorales (Mucor, Absidia, and Rhizopus) are seen increasingly in immune-compromised hosts [50]. Mucorales infections are typically an airborne disease, initiated in the upper or lower airways and have clinical symptoms similar to those of aspergillosis [51-53].

Other invasive infections

Rarer opportunistic pathogens that have emerged during recent years include Penicillium marneffei, Fusarium spp., Malassezia spp.,
Trichosporon spp., Saccharomyces cerevisiae, and Blastoschizomyces capitatus [54-57]. Invasive infection by Malassezia furfur, a commensal yeast normally associated with the superficial fungal infection. Tinea versicolor has also increased in frequency in recent years and is associated with parenteral nutrition [58].

\section{Endemic pathogens}

Systemic endemic mycoses include a group of dimorphic fungi that are found in distinct geographical regions [59]

Blastomycosis

Blastomycosis is the dimorphic fungi caused by the pathogens Blastomyces dermatitidis and Blastomyces gilchristii, which are found in humid soil containing decaying vegetation or decomposed wood and are associated with freshwater drainage basins [60]. It is reported mainly in North America and in Africa but occasionally has also been reported in Central and South America, Mexico, India, and the Middle East [61].

\section{Histoplasmosis}

Histoplasmosis caused by the dimorphic fungus Histoplasma capsulatum is found worldwide, but particularly in North, Central, and South America. Depending on the immune status of the host and the infectious dose, the clinical manifestations vary. In immunocompetent persons, the disease is usually asymptomatic or manifests as an acute respiratory illness that is self-limiting, whereas in immuno-compromised persons, it can result in severe illness with progressive pulmonary disease or disseminated infection. Symptoms are usually mild, but due to heavy exposure of fungus in individuals may cause fever, chills, headache, myalgia, anorexia, cough, and chest pain [62-64] 
Coccidioidomycosis

It is endemic in the southwestern parts of the USA (California, Arizona, New Mexico, Utah, and Nevada) and parts of Central and South America (Mexico, Brazil, and Argentina) and caused by the dimorphic fungi Coccidioides immitis and Coccidioides posadasii. The most common clinical manifestations are chest pain, cough, fever, weight loss, and fatigue, often associated with dermatological manifestations including erythema nodosum or erythema multiforme and rheumatological manifestations including myalgia and arthralgia. The disease can also spread from the lungs hematogenously to bones, joints, skin, and the central nervous system [65-71].

Paracoccidioidomycosis

Paracoccidioidomycosis is caused by the dimorphic fungi Paracoccidioides brasiliensis and Paracoccidioides lutzii. These are found in certain parts of South America, especially not only in Brazil but also in Argentina, Colombia, Ecua dor, Peru, and Venezuela [72,73].

Penicilliosis

In Southeast Asia, penicilliosis is now the third most frequently occurring opportunistic infection in HIV-infected patients. Isolated cases have also been reported in western countries caused by P. marneffei [54].

\section{HERBAL ANTIFUNGAL AGENTS}

Medicinal plants are of great importance to the health of individuals and communities, and their importance lies in the chemical substances that produce a definite physiological action on the human body. Many of the pharmaceuticals currently available have a long history of use as herbal remedies including opium, aspirin, digitalis, and quinine while their purification and quantification makes them more predictable and chemical processing can sometimes modify their effects in desirable ways. Herbal remedies tend to have a more complex and subtle mix of chemicals and can sometimes offer access to drugs or combinations of drugs that the pharmaceutical industry has not yet exploited. These natural compounds formed the basis of discovering modern drugs [74-76]. Some of the antifungal drugs most recently introduced in clinical practice are echinocandines and sordarines derived from natural products $[77,78]$. Therefore, there is a need to develop new antifungal agents providing new mechanisms of action, with a broad spectrum of antifungal activity, fewer dose-limiting side effects, and economic $[79,80]$. Some of the plants having wide fungal activity are listed in Table 1. Which will be proved beneficial for the pharmaceutical industry when formulated. Herbal formulations always have attracted considerable attention due to their good activity and comparatively lesser side effects when compared to synthetic drugs [81].

\section{MARKETED PREPARATIONS}

\section{Himalaya V-gel}

Himalaya V-gel consists of persian rose, triphala, and cardamom. Himalaya V-gel is indicated for vaginal candidiasis (fungal yeast infection), vaginal trichomoniasis (parasitic vaginal infection), and nonspecific bacterial vaginitis.

\section{Himalaya hiora mouth wash}

Himalaya hiora mouthwash kills germs, tones gums and refreshes mouth. It contains Meswak, Betel and Bibhitaki. Meswak and (Salvadora persica) tree twigs are popular teeth-cleaning agents, prevent tooth decay, and eliminates toothache and bad breath. Betel (Nagavalli) leaf effectively tackles halitosis, and its mild stimulating properties are beneficial for toothaches. Belleric myrobalan (Bibhitaki) is an antimicrobial and antifungal agent that keeps infections at bay.

\section{Purifica 1\% vaginal gel}

Purifica gel contains Pueraria mirifica root extract.

\section{Himalaya wellness acne-n-pimple cream}

Himalaya acne-n-pimple cream works wonders with the help of natural ingredients such as Lentil, Silk Cotton Tree, Five-leaved Chaste Tree,
Barbados Aloe, and Alum. Lentil's astringent and anti-inflammatory properties help in reducing inflammation associated with acne.

\section{CONCLUSION}

Although wide progress has been made in recent decades in medicine, fungal infections are still an unsolved health problem. It is mainly due to the fact that some of the available antifungal drugs cause resistance. The plant kingdom is a rich source of medicinal preparations that offer a wide chemical diversity, making it of huge potential for new drug development. Phytochemistry of various plant species has indicated that the phytochemicals could be a better source of medicine as compared to synthetically produced drugs. Researchers over the last years have developed a variety of chemical structures with antifungal activity based on natural compounds which are in the process of design and development. Thus, the plant kingdom holds a lot of potential which further needs to be explored in depth.

\section{CONTRIBUTION OF AUTHORS}

We declare that the work was done by the authors named in the article, and all the liabilities pertaining to claims relating to the content of this article will be borne by the authors. Kusum Kaushik, Shweta Agarwal conceived and designed the study. Kusum Kaushik wrote the manuscript, and all the authors read and approved the manuscript for publication.

\section{CONFLICTS OF INTEREST}

No conflicts of interest associated with this article.

\section{REFERENCES}

1. Wisplinghoff H, Seifert H, Wenzel RP, Edmond MB. Current trends in the epidemiology of nosocomial bloodstream infections in patients with hematological malignancies and solid neoplasms in hospitals in the United States. Clin Infect Dis 2003;36:1103-10.

2. Groll AH, Shah PM, Mentzel C, Schneider M, Just-Nuebling G, Huebner K. Trends in the postmortem epidemiology of invasive fungal infections at a university hospital. J Infect 1996;33:23-32.

3. Denning DW, Evans EG, Kibbler CC, Richardson MD, Roberts MM, Rogers TR, et al. Guidelines for the investigation of invasive fungal infections in haematological malignancy and solid organ transplantation. British Society for Medical Mycology. Eur J Clin Microbiol Infect Dis 1997; 16:424-36.

4. Brown GD, Denning DW, Gow NA, Levitz SM, Netea MG, White TC. Hidden killers: Human fungal infections. Sci Transl Med 2012;4:165rv13.

5. Fidel PL Jr., Barousse M, Espinosa T, Ficarra M, Sturtevant J, Martin DH, et al. An intravaginal live Candida challenge in humans leads to new hypotheses for the immunopathogenesis of vulvovaginal candidiasis. Infect Immun 2004;72:2939-46.

6. Byrnes EJ $3^{\text {rd }}, \mathrm{Li}$ W, Lewit Y, Ma H, Voelz K, Ren P, et al. Emergence and pathogenicity of highly virulent Cryptococcus gattii genotypes in the Northwest United States. PLoS Pathog 2010;6:e1000850.

7. Talaviya S, Majmudar F. Recent developments in antifungal agents. Int J Pharm Pharm Sci 2012;4 Suppl 4:4-10.

8. Sathyan G, Ritschel WA, Hussain AS. Transdermal delivery of tacrine: I. Identification of a suitable delivery vehicle. Int J Pharm 1995; $114: 75-83$.

9. Magdum C, Naikwade N, Shah R. Preparation and evaluation of fluconazole topical microemulsion. J Pharm Res 2009;3:557-61.

10. Banerjee M, Ghosh A, Basak S. Comparative evaluation of efficacy and safety of topical fluconazole and clotrimazole in the treatment of tinea corporis. J Pak Assoc Dermatol 2012;22:342-9.

11. Gungor S, Erdal M, Aksu B. New formulation strategies in topical antifungal therapy. J Cosmet Dermatol Sci Appl 2013;3:56-65.

12. Chen SC, Sorrell TC. Antifungal agents. Med J Aust 2007; 187:404-9.

13. Gupta AK, Sauder DN, Shear NH. Antifungal agents: An overview. Part I. J Am Acad Dermatol 1994;30:677-98.

14. Gupta AK, Sauder DN, Shear NH. Antifungal agents: An overview. Part II. J Am Acad Dermatol 1994;30:911-33.

15. Crawford F, Hollis $\mathrm{S}$. Topical treatments for fungal infections of the skin and nails of the foot. Cochrane Database Syst Rev 2007;3:CD001434.

16. Rotta I, Ziegelmann PK, Otuki MF, Riveros BS, Bernardo NL, Correr CJ. Efficacy of topical antifungals in the treatment of 
dermatophytosis: A mixed-treatment comparison meta-analysis involving 14 treatments. JAMA Dermatol 2013;149:341-9.

17. Ozçelik B, Aslan M, Orhan I, Karaoglu T. Antibacterial, antifungal, and antiviral activities of the lipophylic extracts of Pistacia vera. Microbiol Res 2005;160:159-64.

18. Detandt M, Nolard N. Fungal contamination of the floors of swimming pools, particularly subtropical swimming paradises. Mycoses 1995;38:509-13.

19. Canavan TN, Elewski BE. Identifying signs of tinea pedis: A key to understanding clinical variables. J Drugs Dermatol 2015;14:s42-7.

20. Evans EG. Tinea pedis: Clinical experience and efficacy of short treatment. Dermatology 1997;194 Suppl 1:3-6.

21. Braun-Falco O, Plewig G, Wolff HH, Winkelman RK. Dermatology. $2^{\text {nd }}$ ed. Berlin, Heidelberg: Springer Verlag; 1991.

22. Arnold HL, Odom R, William J. Andrews' Diseases of the Skin. $8^{\text {th }}$ ed. Philadelphia: W.B. Saunders; 1990.

23. Semel JD, Goldin H. Association of athlete's foot with cellulitis of the lower extremities: Diagnostic value of bacterial cultures of ipsilateral interdigital space samples. Clin Infect Dis 1996;23:1162-4

24. Fuller LC, Barton RC, Mohd Mustapa MF, Proudfoot LE, Punjabi SP, Higgins EM. British association of dermatologists' guidelines for the management of tinea capitis 2014. Br J Dermatol 2014;171:454-63.

25. Elewski BE. Tinea capitis: A current perspective. J Am Acad Dermatol 2000;42:1-20

26. Tosti A, Piraccini BM, Lorenzi S. Onychomycosis caused by nondermatophytic molds: Clinical features and response to treatment of 59 cases. J Am Acad Dermatol 2000;42:217-24

27. Ellis DH, Watson AB, Marley JE, Williams TG. Non-dermatophytes in onychomycosis of the toenails. Br J Dermatol 1997;136:490-3.

28. Greer DL. Evolving role of nondermatophytes in onychomycosis. Int J Dermatol 1995;34:521-4.

29. Velegraki A, Cafarchia C, Gaitanis G, Iatta R, Boekhout T. Malassezia infections in humans and animals: Pathophysiology, detection, and treatment. PLoS Pathog 2015;11:e1004523.

30. Sobel JD. Recurrent vulvovaginal candidiasis. Am J Obstet Gynecol 2016;214:15-21.

31. Rios-Fabra A, Moreno AR, Istúriz RE. Fungal infection in Latin American countries. Infect Dis Clin North Am 1994;8:129-54.

32. Sharkey-Mathis PK, Kauffman CA, Graybill JR, Stevens DA, Hostetler JS, Cloud G, et al. Treatment of sporotrichosis with itraconazole. NIAID mycoses study group. Am J Med 1993;95:279-85.

33. Chapman SW, Daniel CR $3^{\text {rd }}$. Cutaneous manifestations of fungal infection. Infect Dis Clin North Am 1994;8:879-910.

34. Lilic D, Cant AJ, Abinun M, Calvert JE, Spickett GP. Chronic mucocutaneous candidiasis. I. Altered antigen-stimulated IL-2, IL4, IL-6 and interferon-gamma (IFN-gamma) production. Clin Exp Immunol 1996;105:205-12.

35. Lilic D, Calvert JE, Cant AJ, Abinun M, Spickett GP. Chronic mucocutaneous candidiasis. II. Class and subclass of specific antibody responses in vivo and in vitro. Clin Exp Immunol 1996;105:213-9.

36. Paterson DL, Singh N. Invasive aspergillosis in transplant recipients. Medicine (Baltimore) 1999;78:123-38

37. Pfaller MA, Diekema DJ. Epidemiology of invasive candidiasis: A persistent public health problem. Clin Microbiol Rev 2007;20:133-63.

38. Pfaller MA, Jones RN, Messer SA, Edmond MB, Wenzel RP. National surveillance of nosocomial blood stream infection due to Candida albicans: Frequency of occurrence and antifungal susceptibility in the SCOPE program. Diagn Microbiol Infect Dis 1998;31:327-32.

39. Pfaller MA, Jones RN, Messer SA, Edmond MB, Wenzel RP. National surveillance of nosocomial blood stream infection due to species of Candida other than Candida albicans: Frequency of occurrence and antifungal susceptibility in the SCOPE program. SCOPE participant group. Surveillance and control of pathogens of epidemiologic. Diagn Microbiol Infect Dis 1998;30:121-9.

40. Bodey GP, Buckley M, Sathe YS, Freireich EJ. Quantitative relationships between circulating leukocytes and infection in patients with acute leukemia. Ann Intern Med 1966;64:328-40.

41. Beck-Sagué C, Jarvis WR. Secular trends in the epidemiology of nosocomial fungal infections in the United States, 1980-1990. National nosocomial infections surveillance system. J Infect Dis 1993; 167:1247-51.

42. Rangel-Frausto MS, Wiblin T, Blumberg HM, Saiman L, Patterson J, Rinaldi M, et al. National epidemiology of mycoses survey (NEMIS): Variations in rates of bloodstream infections due to Candida species in seven surgical intensive care units and six neonatal intensive care units. Clin Infect Dis 1999;29:253-8

43. Odds FC. Epidemiological shifts in opportunistic and nosocomial
Candida infections: Mycological aspects. Int J Antimicrob Agents 1996;6:141-4.

44. Abi-Said D, Anaissie E, Uzun O, Raad I, Pinzcowski H, Vartivarian S, et al. The epidemiology of hematogenous candidiasis caused by different Candida species. Clin Infect Dis 1997;24:1122-8.

45. Wingard JR, Merz WG, Rinaldi MG, Johnson TR, Karp JE, Saral R. Increase in Candida krusei infection among patients with bone marrow transplantation and neutropenia treated prophylactically with fluconazole. N Engl J Med 1991;325:1274-7.

46. Walsh TJ, Dixon DM. Nosocomial aspergillosis: Environmental microbiology, hospital epidemiology, diagnosis and treatment. Eur J Epidemiol 1989;5:131-42.

47. Dromer F, Mathoulin S, Dupont B, Laporte A. Epidemiology of cryptococcosis in France: A 9-year survey (1985-1993). French Cryptococcosis Study Group. Clin Infect Dis 1996;23:82-90.

48. Ruggieri M, Polizzi A, Vitaliti MC, Magro G, Musumeci S. Fatal biphasic brainstem and spinal leptomeningitis with Cryptococcus neoformans in a non-immunocompromised child. Acta Paediatr 1999;88:671-4.

49. Mitchell DH, Sorrell TC, Allworth AM, Heath $\mathrm{CH}$, McGregor AR, Papanaoum K, et al. Cryptococcal disease of the CNS in immunocompetent hosts: Influence of cryptococcal variety on clinical manifestations and outcome. Clin Infect Dis 1995;20:611-6.

50. Sugar AM. Mucormycosis. Clin Infect Dis 1992;14 Suppl 1:S126-9.

51. Reingold AL, Lu XD, Plikaytis BD, Ajello L. Systemic mycoses in the United States, 1980-1982. J Med Vet Mycol 1986;24:433-6.

52. Klein BS, Vergeront JM, Davis JP. Epidemiologic aspects of blastomycosis, the enigmatic systemic mycosis. Semin Respir Infect 1986;1:29-39.

53. Kirkland TN, Fierer J. Coccidioidomycosis: A reemerging infectious disease. Emerg Infect Dis 1996;2:192-9.

54. Duong TA. Infection due to Penicillium marneffei, an emerging pathogen: Review of 155 reported cases. Clin Infect Dis 1996;23:125-30.

55. Fridkin SK, Jarvis WR. Epidemiology of nosocomial fungal infections. Clin Microbiol Rev 1996;9:499-511.

56. Krcmery V, Krupova I, Denning DW. Invasive yeast infections other than Candida spp. in acute leukaemia. J Hosp Infect 1999;41:181-94.

57. Boutati EI, Anaissie EJ. Fusarium, a significant emerging pathogen in patients with hematologic malignancy: Ten years' experience at a cancer center and implications for management. Blood 1997;90:999-1008.

58. Marcon MJ, Powell DA. Epidemiology, diagnosis, and management of Malassezia furfur systemic infection. Diagn Microbiol Infect Dis 1987;7:161-75.

59. Mirsaeidi M, Motahari H, Taghizadeh Khamesi M, Sharifi A, Campos M, Schraufnagel DE. Climate change and respiratory infections. Ann Am Thorac Soc 2016;13:1223-30.

60. McTaggart LR, Brown EM, Richardson SE. Phylogeographic analysis of Blastomyces dermatitidis and Blastomyces gilchristii reveals an association with North American freshwater drainage basins. PLoS One 2016;11:e0159396.

61. Roy M, Benedict K, Deak E, Kirby MA, McNiel JT, Sickler CJ, et al. A large community outbreak of blastomycosis in Wisconsin with geographic and ethnic clustering. Clin Infect Dis 2013;57:655-62.

62. Wheat LJ, Conces D, Allen SD, Blue-Hnidy D, Loyd J. Pulmonary histoplasmosis syndromes: Recognition, diagnosis, and management. Semin Respir Crit Care Med 2004;25:129-44.

63. Benedict K, Derado G, Mody RK. Histoplasmosis-associated hospitalizations in the United States, 2001-2012. Open Forum Infect Dis 2016;3:ofv219.

64. Capone D, Wanke B, Monteiro PC, Lazéra MS, de Noronha Andrade G, do Valle AC, et al. Chronic pulmonary histoplasmosis in the state of Rio de Janeiro, Brazil. Mycopathologia 1999;145:75-9.

65. Galgiani JN, Ampel NM, Blair JE, Catanzaro A, Johnson RH, Stevens DA, et al. Infectious diseases society of America: Coccidioidomycosis. Clin Infect Dis 2005;41:1217-23

66. Nicas M. A point-source outbreak of coccidioidomycosis among a highway construction crew. J Occup Environ Hyg 2018;15:57-62.

67. Crum N, Lamb C, Utz G, Amundson D, Wallace M. Coccidioidomycosis outbreak among united states navy SEALs training in a Coccidioides immitis-endemic area-coalinga, California. J Infect Dis 2002;186:865-8.

68. Petersen LR, Marshall SL, Barton-Dickson C, Hajjeh RA, Lindsley MD, Warnock DW, et al. Coccidioidomycosis among workers at an archeological site, Northeastern Utah. Emerg Infect Dis 2004; 10:637-42.

69. Williams PL, Sable DL, Mendez P, Smyth LT. Symptomatic coccidioidomycosis following a severe natural dust storm. An outbreak at the Naval Air Station, Lemoore, Calif. Chest 1979;76:566-70. 
70. Osaki T, Morishita H, Maeda H, Kamei K, Hoshino S, Kijima T, et al. Pulmonary coccidioidomycosis that formed a fungus ball with 8-years duration. Intern Med 2005;44:141-4.

71. Capone D, Marchiori E, Wanke B, Dantas KE, Cavalcanti MA, Deus Filho A, et al. Acute pulmonary coccidioidomycosis: CT findings from 15 patients. Br J Radiol 2008;81:721-4.

72. Shikanai-Yasuda MA, Mendes RP, Colombo AL, Queiroz-Telles F, Kono AS, Paniago AM, et al. Brazilian guidelines for the clinical management of paracoccidioidomycosis. Rev Soc Bras Med Trop 2017;50:715-40.

73. Bethlem EP, Capone D, Maranhao B, Carvalho CR, Wanke B. Paracoccidioidomycosis. Curr Opin Pulm Med 1999;5:319-25.

74. Edeoga HO, Okwu DE, Mbaebie BO. Phytochemical constituents of some Nigerian medicinal plants. Afr J Biotech 2005;4:685-8

75. Akinmo-Laudn AC, Ibukun EO, Afor E, Obuotor EM, Farombi EO. Phytochemical constituents and antioxidant activity of extracts from leaves of $O$. gratissimum. Sci Res Essays 2007;2:163-6.

76. Rout SP, Choudhary KA, Kar DM, Das L, Jain A. Plants in traditional medicinal system-future source of new drugs. Int J Pharm Pharm Sci 2009;1:1-23.

77. Di Santo R. Natural products as antifungal agents against clinically relevant pathogens. Nat Prod Rep 2010;27:1084-98.

78. Tomishima M, Ohki H, Yamada A, Maki K, Ikeda F. Novel echinocandin antifungals. Bioorg Med Chem Lett 2008;18:1474-7.

79. Abad MJ, Ansuategui M, Bermejo P. Active antifungal substances from natural sources. Arkivoc 2007;7:116-45.

80. Barrett D. From natural products to clinically useful antifungals. Biochim Biophys Acta 2002;1587:224-33

81. Taha KF, EL-Hawary SS, EL-Hefnawy HM, Mabrouk MI, Sanad RA, Harriry MY. Formulation and assessment of a herbal hair cream against certain dermatophytes. Int J Pharm Pharm Sci 2016;8:167-73.

82. De Leo M, Braca A, De Tommasi N, Norscia I, Morelli I, Battinelli L, et al. Phenolic compounds from Baseonema acuminatum leaves: Isolation and antimicrobial activity. Planta Med 2004;70:841-6.

83. Rubio OC, Cuellar AC, Rojas N, Castro HV, Rastrelli L, Aquino R. A polyisoprenylated benzophenone from Cuban propolis. J Nat Prod 1999;62:1013-5.

84. Dharmaratne HR, Piyasena KG, Tennakoon SB. A geranylated biphenyl derivative from Garcinia malvgostana. Nat Prod Res 2005;19:239-43.

85. Nkunya MH, Makangara JJ, Jonker SA. Prenylindoles from Tanzanian monodora and Isolona species. Nat Prod Res 2004;18:253-8.

86. Lee DG, Park Y, Kim MR, Jung HJ, Seu YB, Hahm KS, et al. Antifungal effects of phenolic amides isolated from the root bark of Lycium chinense. Biotechnol Lett 2004;26:1125-30.

87. Perry NB, Brennan NJ. Antimicrobial and cytotoxic phenolic glycoside esters from the New Zealand tree Toronia toru. J Nat Prod 1997;60:623-6.

88. Tan RX, Lu H, Wolfender JL, Yu TT, Zheng WF, Yang L, et al. Mono- and sesquiterpenes and antifungal constituents from Artemisia species. Planta Med 1999;65:64-7.

89. Bylka W, Szaufer-Hajdrych M, Matławska I, Goślińska O. Antimicrobial activity of isocytisoside and extracts of Aquilegia vulgaris L. Lett Appl Microbiol 2004;39:93-7.

90. Rao MS, Duddeck H, Dembinski R. Isolation and structural elucidation of 3,4',5,7-tetraacetyl quercetin from Adina cordifolia (Karam Ki Gaach). Fitoterapia 2002;73:353-5.

91. Meragelman TL, Tucker KD, McCloud TG, Cardellina JH $2^{\text {nd }}$, Shoemaker RH. Antifungal flavonoids from Hildegardia barteri. J Nat Prod 2005;68:1790-2

92. Hunter MD, Hull LA. Variation in the concentration of phloridzin and phloretin in apple foliage. Phytochemistry 1993;34:1251-4.

93. De Campos MP, Cechinel Filho V, Da Silva RZ, Yunes RA, Zacchino S, Juarez S, et al. Evaluation of antifungal activity of Piper solmsianum C. DC. Var. solmsianum (Piperaceae). Biol Pharm Bull 2005;28:1527-30.

94. Jung HJ, Sung WS, Yeo SH, Kim HS, Lee IS, Woo ER, et al. Antifungal effect of amentoflavone derived from Selaginella tamariscina. Arch Pharm Res 2006;29:746-51.

95. Sunthitikawinsakul A, Kongkathip N, Kongkathip B, Phonnakhu S, Daly JW, Spande TF, et al. Coumarins and carbazoles from Clausena excavata exhibited antimycobacterial and antifungal activities. Planta Med 2003;69:155-7.

96. Carpinella MC, Ferrayoli CG, Palacios SM. Antifungal synergistic effect of scopoletin, a hydroxycoumarin isolated from Melia azedarach L. fruits. J Agric Food Chem 2005;53:2922-7.

97. Rahalison L, Benathan M, Monod M, Frenk E, Gupta MP, Solis PN, et al. Antifungal principles of Baccharis pedunculata. Planta Med
1995;61:360-2

98. Kofinas C, Chinou I, Loukis A, Harvala C, Roussakis C, Maillard M, et al. Cytotoxic coumarins from the aerial parts of Tordylium apulum and their effects on a non-small-cell bronchial carcinoma line. Planta Med 1998;64:174-6.

99. Shanker KS, Kanjilal S, Rao BV, Kishore KH, Misra S, Prasad RB. Isolation and antimicrobial evaluation of isomeric hydroxy ketones in leaf cuticular waxes of Annona squamosa. Phytochem Anal 2007;18:7-12.

100. Binutu OA, Adesogan KE, Okogun JI. Antibacterial and antifungal compounds from Kigelia pinnata. Planta Med 1996;62:352-3.

101. Manojlovic NT, Solujic S, Sukdolak S, Milosev M. Antifungal activity of Rubia tinctorum, Rhamnus frangula and Caloplaca cerina. Fitoterapia 2005;76:244-6.

102. Escalante AM, Santecchia CB, López SN, Gattuso MA, Gutiérrez Ravelo A, Delle Monache F, et al. Isolation of antifungal saponins from Phytolacca tetramera, an Argentinean species in critic risk. J Ethnopharmacol 2002;82:29-34

103. Du Z, Zhu N, Ze-Ren-Wang-Mu N, Shen Y. Two new antifungal saponins from the Tibetan herbal medicine Clematis tangutica. Planta Med 2003;69:547-51

104. Sautour M, Miyamoto T, Lacaille-Dubois MA. Steroidal saponins from Smilax medica and their antifungal activity. J Nat Prod 2005;68:1489-93.

105. Xie BB, Liu HY, Ni W, Chen CX, Lü Y, Wu L, et al. Five new steroidal compounds from Ypsilandra thibetica. Chem Biodivers 2006;3:1211-8.

106. Larcher G, Morel C, Tronchin G, Landreau A, Séraphin D, Richomme P, et al. Investigation of the antifungal activity of caledonixanthone $\mathrm{E}$ and other xanthones against Aspergillus fumigatus. Planta Med 2004;70:569-71.

107. Joseph CC, Moshi MJ, Sempombe J, Nkunya MH. (4-methoxybenzo[1,3]dioxol-5-Y1)-phenylmethanone: An antibacterial bnenzophenone from Securidaca longepedunculata. Afr J Trad CAM 2006;3:80-6.

108. Pinto DC, Fuzzati N, Pazmino XC, Hostettmann K. Xanthone and antifungal constituents from Monnina obtusifolia. Phytochemistry 1994;37:875-8.

109. Wang YH, Hou AJ, Zhu GF, Chen DF, Sun HD. Cytotoxic and antifungal isoprenylated xanthones and flavonoids from Cudrania fruticosa. Planta Med 2005;71:273-4.

110. Klausmeyer P, Chmurny GN, McCloud TG, Tucker KD, Shoemaker RH. A novel antimicrobial indolizinium alkaloid from Aniba panurensis. J Nat Prod 2004;67:1732-5.

111. Singh NV, Azmi S, Maurya S, Singh UP, Jha RN, Pandey VB. Two plant alkaloids isolated from Corydalis longipes as potential antifungal agents. Folia Microbiol (Praha) 2003;48:605-9.

112. Dabur R, Chhillar AK, Yadav V, Kamal PK, Gupta J, Sharma GL. In vitro antifungal activity of 2-(3,4-dimethyl-2,5-dihydro-1H-pyrrol2-yl)-1-methylethyl pentanoate, a dihydropyrrole derivative. J Med Microbiol 2005;54:549-52.

113. Morteza-Semnani K, Amin G, Shidfar MR, Hadizadeh H, Shafiee A. Antifungal activity of the methanolic extract and alkaloids of Glaucium oxylobum. Fitoterapia 2003;74:493-6.

114. Emile A, Waikedre J, Herrenknecht C, Fourneau C, Gantier JC, Hnawia $\mathrm{E}$, et al. Bioassay-guided isolation of antifungal alkaloids from Melochia odorata. Phytother Res 2007;21:398-400.

115. Liu SC, Oguntimein B, Hufford CD, Clark AM. 3-methoxysampangine, a novel antifungal copyrine alkaloid from Cleistopholis patens. Antimicrob Agents Chemother 1990;34:529-33.

116. Rahman AU, Nasreen A, Akhtar F, Shekhani MS, Clardy J, Parvez M, et al. Antifungal diterpenoid alkaloids from Delphinium denudatum. J Nat Prod 1997;60:472-4.

117. Wang F, Yang D, Ren S, Zhang H, Li R. Chemical composition of essential oil from leaves of Litsea cubeba and its antifungal activities. Zhong Yao Cai 1999;22:400-2.

118. Marthanda Murthy M, Subramanyam M, Hima Bindu M, Annapurna J. Antimicrobial activity of clerodane diterpenoids from Polyalthia longifolia seeds. Fitoterapia 2005;76:336-9.

119. Portillo A, Vila R, Freixa B, Ferro E, Parella T, Casanova J, et al. Antifungal sesquiterpene from the root of Vernonanthura tweedieana. J Ethnopharmacol 2005;97:49-52.

120. Ye XY, Ng TB. Purification of angularin, a novel antifungal peptide from adzuki beans. J Pept Sci 2002;8:101-6.

121. Ye XY, Ng TB, Rao PF. Cicerin and arietin, novel chickpea peptides with different antifungal potencies. Peptides 2002;23:817-22.

122. Taira T, Toma N, Ishihara M. Purification, characterization, and antifungal activity of chitinases from pineapple (Ananas comosus) leaf. Biosci Biotechnol Biochem 2005;69:189-96. 